\title{
TITLE:
}

\section{Nonlinear Digital Hearing Aid with Near-Instantaneous Amplitude Compression(Abstract_要旨)}

$\operatorname{AUTHOR}(S)$ :

Kaneko, Kenichi

\section{CITATION:}

Kaneko, Kenichi. Nonlinear Digital Hearing Aid with Near-Instantaneous Amplitude Compression. 京都大学, 2002, 博士(医学)

ISSUE DATE:

2002-01-23

URL:

http://hdl.handle.net/2433/150217

RIGHT: 


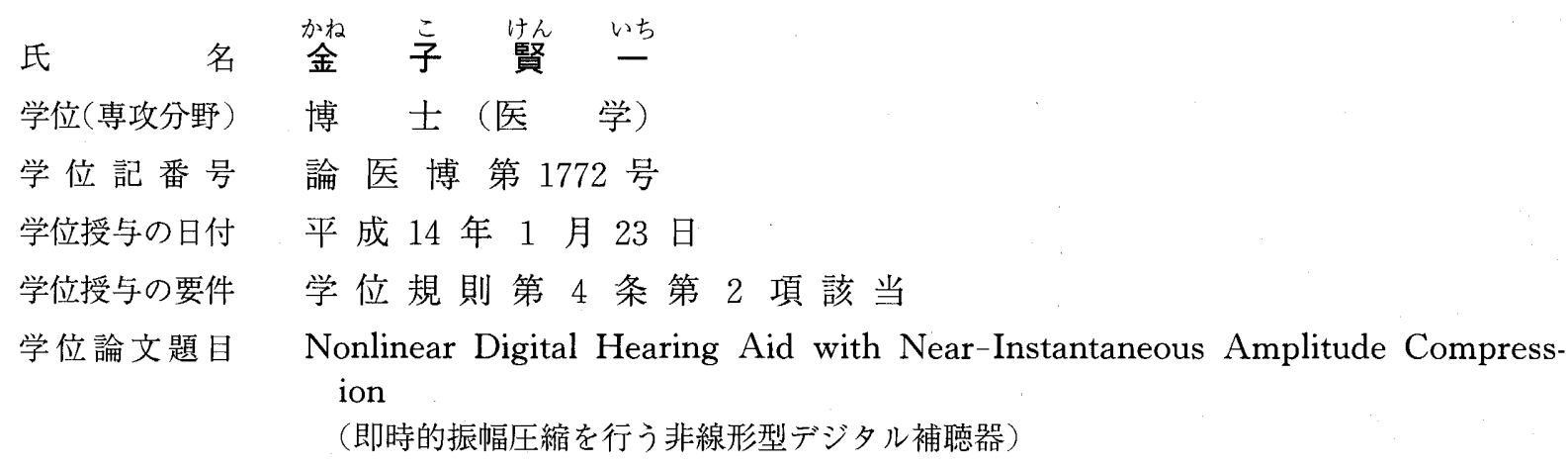

論文調査委員 教授) 野間昭 典教授堤定美教授伊藤壽一

\section{論文内容 の 要旨}

ほとんどの感音性難聴者は聞き取れる音のダイナミックレンジが減少しているため, 最近では多数の補聴器が信号のレべ ルレンジを小さく圧縮する機能を備えている。しかし従来の圧縮方法では，言葉や環境音のようなレベルが急激に，また頻 回に変化する信号に対しては，その正確なレベルを検知し適切なゲインを決定することは困難であった。

これを克服するため, 即時的に振幅の非線形圧縮を行うデジタル補聴器（TD-1）を新たに開発した。この補聴器に採用 された増幅方法は，信号波形が負から正に変化する零交叉点と次の零交叉点との間で区切られた時間空内で波形を正規化す る,というものである。すなわち，各時間空内の信号の最大振幅点があらかじめ設定された振幅となるような増幅率で，時 間悹ごとに増幅率を変えつつ, 最大振幅が一定となるように次々に増幅を行っていく。この処理によって振幅が小さい子音 部分が強調され，また母音部分のフォルマントなどの周波数情報はよく保たれる。一方，衝撃音のような振幅が大きい音が 入った場合,これは完全に抑制される。

この補聴器の効果を確かめるため, 31名の感音性難聴者（男性17名, 女性14名, 12〜90歳, 平均年齢64.1歳）に対し, 静 かな環境で補聴器装用下に日本語の文章を用いて聞き取りの検査を行った。被検者の聴力レベルは $43.3 〜 105.0 \mathrm{dBHL}$ で, 15名の中等度および16名の高度難聴者を含んでいた。また25名は既に補聴器使用者であった。補聴器はTD-1 と，従来型 アナログ補聴器 HA70 またはHA73 と，被検者が通常使用しているアナログ補聴器を使用した。検査にあたり 5 文，20文 節からなる文章の組み合わせを 12 種類作成し，1 種類の呈示音圧レベルおよび 1 種類の補聴器につき, 文章の組み合わせを このうちから 1 種類ランダムに選択して用いた。文章の呈示音圧レベルは50, 60, 70, $80 \mathrm{dBSPL}$ の 4 種類で, 補聴器を装 用した被検者にこれらを聞かせ復唱させて，その文節の正答率を比較した。

その結果は，1）呈示音圧レベルが50dBSPLのとき，50\%以上の正答率を示したのは被検者自身の補聴器装用時で25名 中 0 名 $(0 \%), \mathrm{HA} 70$ またはHA73 装用時で31名中 2 名（6.5\%）であったのに対し，TD-1装用時では31名中 9 名 (29.0\%)であった。さらにこの 9 名はすべての呈示音圧レベルにおいて正答率が50\%以上であった。また，2）4種類の 呈示音圧レベルにおける正答率のうち最も良いものを最大認知スコアと定め補聴器間で比較したところ, TD-1 と被検者自 身の補聴器との比較では25名中 7 名 $(28.0 \%)$ が，またHA70またはHA73 との比較では31名中 7 名（22.6\%）が TD-1 のほうが20\%以上良好であった。

このように, TD-1によって良好な成績が得られた感音性難聴者が存在した。また，言葉の呈示音圧レベルが十分大きい

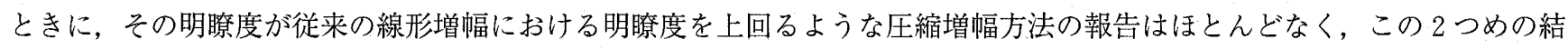
果は特に重要であるといえる。このような良好な結果が得られたのは, この增幅法が言葉のもつ周波数情報を保持する一方， 時間情報もよく伝えるからではではないかと考えられる。またTD-1 は操作も簡単で, 増幅に必要な演算回数が少なく消 費電力を抑えることができるため，現在の試作機は箱型であるが将来的には小型化も可能である。以上より，TD-1は感音 性難聴者にとって有用な補聴器であると考えられる。 
感音難聴者は聴覚のダイナミックレンジが狭いため, 近年多数の補聴器が信号のレベルレンジを小さく圧縮する機能を備 えているが, 従来の方法では正確な入力信号レベルを検知し適切なゲインを与えることは困難であった。申請者は, 即時的 振幅圧縮法，すなわち信号波形が負から正に变化する零交叉点と次の零交叉点との間で区切られた時間空内で波形を正規化 する，という非線形増幅法ならびにそれを採用したデジタル補聴器（TD-1）を開発し，これが感音難聴者の語音聴取能改 善に有用であると考えた。そこで, 感音難聴者に対し本補聴器㧍よび従来式補聴器を用いて補聴器装用下に語音聴力検査を 行い, 各補聴器によ, る語音聴取成績を比較した。

その結果, この補聴器によって（1）語音の呈示音圧レベルにかかわらず良好な語音明瞭度が得られた。（2）その最高 語音明瞭度が，線形増幅における最高語音明瞭度を上回る難聴者がみられた。このように，本補聴器によって従来の補聴器 を上回る聴取成績を得られる感音難聴者がいることが明らかになった。

以上の研究は, 即時的振幅圧縮法というきわめて独創的な増幅方法を用いた補聴器が, 感音難聴者の語音聴取能改善に有 用であることを示したものである。

したがって, 本論文は博士 (医学) の学位論文として価値あるものと認める。な拉，本学位授与申請者は，平成13年12月 17日実施の論文内容とそれに関連した研究分野ならびに学識確認のための諮問を受け，合格と認められたものである。 